\title{
AN ATTEMPT TO IDENTIFY THE SEASONALITY OF HOUSING PRICES IN SELECTED POLISH CITIES IN 1996-2012
}

\author{
Radosław Trojanek, PhD \\ Department of Spatial and Environmental Economics \\ Poznań University of Economics \\ e-mail:r.trojanek@ue.poznan.pl
}

\begin{abstract}
Markets of any goods, like the whole economy, are subject to fluctuations, which are usually determined by the economic situation. Fluctuations of different strength affect all markets, including that of real estate. Studies conducted in other countries show that the number of transactions and the price of apartments on the housing market tend to increase in the spring and summer rather than in autumn and winter. In this paper, an attempt was made to verify this relation in Polish conditions using examples of several cities in the period of 1996-2012.
\end{abstract}

Keywords: housing market, house prices, seasonality in housing market.

JEL Classification: R31.

Citation: Trojanek R., (2013), "An attempt to identify the seasonality of housing prices in the selected cities of Poland in 1996-2012", Real Estate Management and Valuation, vol. 21, no. 4, pp. 96-103.

DOI: $10.2478 /$ remav-2013-0041.

\section{Introduction}

In recent years, housing markets, just as price changes in these markets, have become a frequent subject of scientific research throughout the world. There are a number of reasons for the increased interest in this area of study. The most important of them is the cyclicality of housing prices, which has been proved by numerous studies, on the markets of different countries. Price fluctuations in the housing market are usually a result of changes in the economic situation, although some researchers attempted to identify oscillations of a different nature. However, studies carried out in a number of countries indicate seasonality in the number of completed transactions on the housing market (Handbook on RPPI Version 3.0 January 2011). A problem arises when we attempt to answer the question of whether this seasonality leads to seasonality in the prices of apartments. The answer is unequivocal. Studies conducted on housing markets in Great Britain and the United States suggest that seasonality exists in time series of home prices (KUO 1996; KAJUTH, SCHMIDT 2011; MiLlER, SAH, SKlarZ, PAMPUlov 2011; KAPLANSKI, LeVY 2012). In the Polish case, difficulty in identifying seasonality lies in the following factors:

- it requires a lot of effort to gather information about all transactions (involving both apartments with full ownership and those with a limited right of ownership) in a given local housing market over a period of more than five years,

- the fact that a time series of apartment prices which does not take into account the qualitative and quantitative changes in the housing market is used may affect the obtained results,

- in the case of the primary market, transaction prices from notarial deeds in which transactions were pledged some time earlier may cause prices from these deeds not to reflect the current market situation.

Therefore, an attempt to identify seasonal phenomena in a time series of apartment prices in five 
cities in Poland in 1996-2012 was undertaken in this article.

\section{Time series components}

The analysis of time series concerning different economic phenomena indicates that changes in the level of business activity are influenced by a variety of economic, social, political and natural factors which contribute to the occurrence of fluctuations of different length (Koniunktura na rynku bankowym $i$ ubezpieczeniowym 2001). Fluctuations in time series may be divided, according to their duration, into: development tendencies (trends), random fluctuations, seasonal fluctuations and cyclical fluctuations.

Development tendencies (trends) refer to long-term, regular change trends (growth or decline) of a particular variable under study. Trends may be used to illustrate the development tendency of a process, which facilitates the retrospective description of a given phenomenon in time (Koniunktura gospodarcza Polski, Analiza grup produktowych 1997). Trends occur when the variable under study is affected by a certain set of factors, both of an objective and subjective nature.

Seasonal fluctuations are those changes in the intensity of business activity that take place throughout a calendar year and result from phenomena directly or indirectly connected with the seasons of the year. These fluctuations recur with high regularity over a certain period of time, which is not longer than one calendar year, and may be divided into two categories. The first type of seasonal fluctuations occurs in monthly, quarterly and six-month series and first of all, reflects the influence of the seasons of the year and customs on business activity. The other category of periodic fluctuations includes short-term oscillations, which do not last longer than one month; their phases occur within one day, week or month. They are usually determined by the biological rhythm, the adopted division of labor, or customs (LUBIŃSKI 2002). This type of fluctuations does not occur in most time series analyzed by economists as the series under study are available in the form of monthly, quarterly, six-month or yearly data.

Random fluctuations result from quite unspecified random causes, which are not related to the essence of a given phenomenon. They are irregular in terms of strength and direction (PASCHAWER 1967). Random factors causing such fluctuations include natural phenomena, such as floods, droughts and earthquakes, as well as political events, such as wars and strikes.

Cyclical fluctuations are those recurrent changes in business activity which are reflected in the expansion or shrinking of this activity along the trend line (Koniunktura gospodarcza 1982). They are determined by the behavior of economic factors, which significantly distinguishes them from seasonal fluctuations.

In the time series of variables which describe the housing market we may find trends, seasonal fluctuations, random fluctuations and cyclical fluctuations. These variables may include demand, supply, or prices on the housing market. ${ }^{1}$ As regards housing prices, we observe trends (in most cases, real estate prices have displayed an upward trend, with the exception of Germany and Switzerland, where real estate prices tended to decrease in 1975-2005), seasonal fluctuations (an increase in the number of transactions during summer vacation in the USA), random fluctuations (drops in the prices of apartments in the flooded areas of Wroclaw in 1997), and cyclical fluctuations resulting from economic factors which affect the behavior of the participants of this market.

\section{Sources of data}

In order to identify seasonality in housing prices on the real estate market, information on the asking prices of apartments in the biggest cities of Poland (Cracow, Lodz, Poznan, Warsaw, Wroclaw) in the years 1996-2012 (for the period of 2008-2012 the data included a detailed description of the apartments according to their features) and on the transaction prices of limited rights of ownership to apartments in Poznan in 1996-2010 was collected. As far as time series are concnerned, the average prices of $1 \mathrm{~m}^{2}$ were determined for the period of 1996-2012, hedonic prices of apartments and of $1 \mathrm{~m}^{2}$ for 2008-2012, and average prices of apartments and of $1 \mathrm{~m}^{2}$ for transaction prices in the years 19962010.In Polish conditions, there is limited access to data about transaction prices, especially historical ones. $^{2}$ The data regarding apartment prices originally covered over 1,900,000 offers of apartments for

\footnotetext{
${ }_{1}^{1}$ As it is difficult to assess the size of demand or supply, it is housing prices that are usually the subject of analyses.

2 For a few years, a system of recording prices and value has been developing - at present, such data are available in most big cities. However, they only concern properties with full ownership, while there is no information about apartments with a
} 
sale (in six of the biggest cities in Poland). Empty and recurring records were removed, as well as those in which a specific offer was not fully described. The recurrence of data was the result of announcing one offer by a few estate agents, thus they were repeatedly placed in a database. The next stage of the analysis involved checking the reliability of the obtained data. The aim was to eliminate those offers which strayed, for no clearly specified reasons, far from the average. Moreover, it was assumed that the analysis will cover apartments with a floor space of up to $150 \mathrm{~m}^{2}$ and having no more than five rooms. Both fully owned apartments and ones with a limited right of ownership were examined. As a result of methodological selection ${ }^{3}$, the size of the database was reduced to about $1,000,000$ apartments for sale (230,000 offers in Cracow, 130,000 offers in Lodz, 140,000 offers in Poznan, 350,000 offers in Warsaw and 150,000 offers in Wroclaw). The number of offers gathered meets the requirements for the representativeness of the sample. Figure 1 presents the average nominal prices of $1 \mathrm{~m}^{2}$ of apartments in the Polish cities under study in 1996-2012.

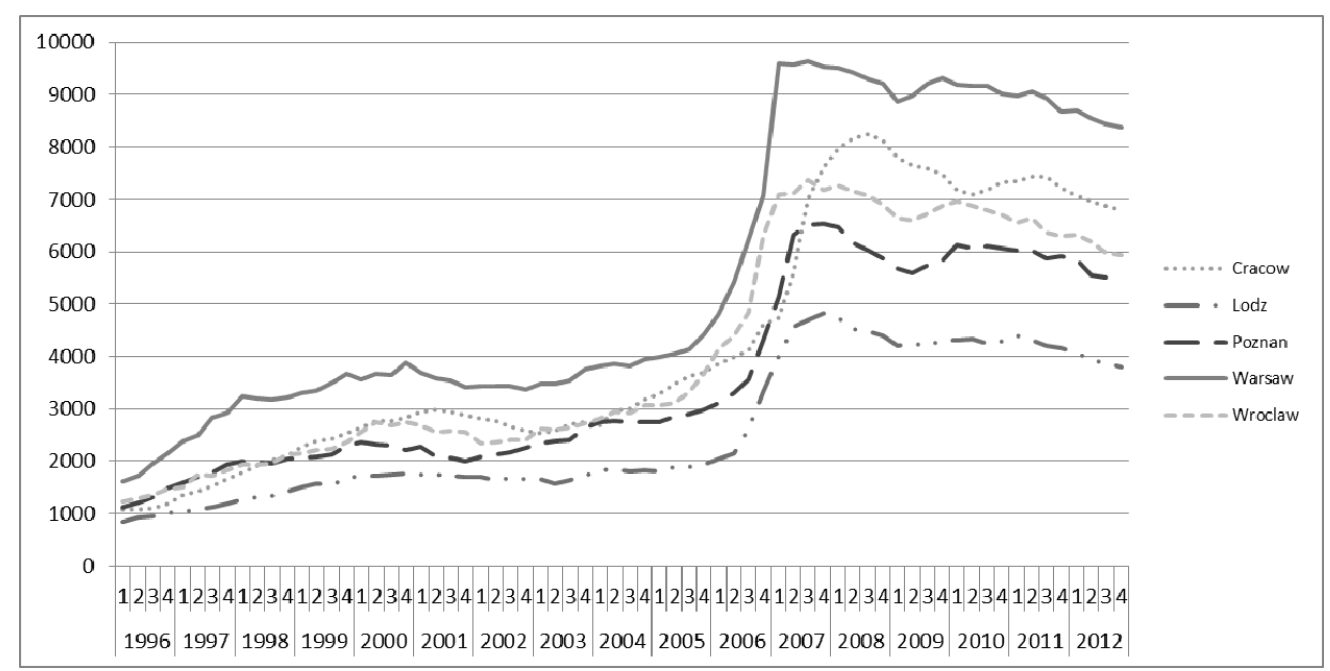

Fig. 1. Average nominal prices of $1 \mathrm{~m}^{2}$ of apartments in the analyzed Polish cities in 1996-2012.

Source: author's own work.

Moreover, information was collected on offers with full characteristics of dwellings in selected cities in the years 2008-2012. This allowed hedonic price models to be computed and, in result, pure price changes to be obtained. As a result of methodological selection, the size of the database was reduced to 290,000 dwellings up for sale (42,097 offers in Cracow, 26,068 in Lodz, 27,904 in Poznan, 178,034 in Warsaw and 21,805 in Wroclaw). The number of offers gathered meets the requirements for the sample to be considered representative. The research was conducted applying the hedonic method based on the housing price regression equation, which includes the time dummy variable. The choice of qualitative and quantitative variables was limited by the availability of information in the database. Table 1 presents the variables used in the research.

\footnotetext{
limited right of ownership in multi-family residentials (such information is only available in the housing cooperatives - there are several dozen of such institutions in big cities). There are different ways of providing these data - in some cities, e.g., in Wroclaw, they may be accessed online; in others, e.g., in Poznan, they are provided in the form of pdf printouts (overall information about transactions), whereas in Warsaw, it is possible to browse and rewrite data only from cards, with the most important information included in notarial deeds. Information about dwellings in multi-family residentials (with a full or limited right of ownership) included in notarial deeds is incomplete from the perspective of their applicability for the construction of indexes with the use of hedonic methods (lack of information about the technology used, time of construction, technical condition of the building, standard of decoration). The situation is even worse in the case of single-family dwelling units (houses). Although it is relatively easy to obtain data about the date of transaction, and the location as well assize of a plot, it is hardly possible to find information about the construction technology, the time of construction, the technical condition, the standard of interior decoration, and the usable floor space. Moreover, even if such information is provided, its type is not specified, e.g.,whether it is the total usable area; if it is usable, what norm was used for estimating it; the floor space for tax calculations...).
} 
Qualitative and quantitative variables used in the model

Table 1

\begin{tabular}{|c|c|c|}
\hline Variable & Symbol & Description \\
\hline Period & $\begin{array}{l}Q 1-20081 q . \\
\ldots 20 \\
Q 20124 q .\end{array}$ & $\begin{array}{l}20 \text { time dummy variables. It takes the value of } 1 \text { if } \\
\text { the dwelling was offered for sale in a given period; } \\
\text { otherwise, it takes } 0 .\end{array}$ \\
\hline Location & $d 1 \ldots d 18$ & $\begin{array}{l}\text { Time dummy variables. The administrative division } \\
\text { of cities was used (Cracow - } 18 \text { variables, Lodz - } 5 \\
\text { variables, Poznan - } 5 \text { variables, Warsaw - } 18 \\
\text { variables, Wroclaw - } 5 \text { variables). If the dwelling is } \\
\text { located in a given district, it takes the value of } 1 \text {; } \\
\text { otherwise, it takes } 0 \text { ). }\end{array}$ \\
\hline Material & $m$ & $\begin{array}{c}\text { 1-prefabricated } \\
\text { 2-traditional technology } \\
\end{array}$ \\
\hline Time of construction & $\begin{array}{l}o b \_1-\text { before } 1939 \\
o b \_2-\text { from } 1945 \text { to } \\
1989 \\
o b \_3-\text { after } 1990\end{array}$ & $\begin{array}{l}3 \text { time dummy variables. If the dwelling is placed in } \\
\text { a building built in a given period, it takes the value } \\
\text { of } 1 \text {; otherwise, it takes } 0 \text { ). }\end{array}$ \\
\hline Floor space & pow & $\begin{array}{c}\text { The floor area of a given dwelling is measured in } \\
\text { square meters. }\end{array}$ \\
\hline Floor & $p$ & $\begin{array}{c}1 \text { - ground and top floor } \\
2 \text { - intermediate floors } \\
3 \text { - first and second floor }\end{array}$ \\
\hline Type of ownership & $p w$ & $\begin{array}{c}\text { 1-limited right of ownership } \\
2 \text { - full ownership }\end{array}$ \\
\hline Standard & $s$ & $\begin{array}{l}\text { It takes the value of } 1 \text { for dwellings with the lowest } \\
\text { standard, and } 5 \text { for those with the highest. }\end{array}$ \\
\hline
\end{tabular}

Source: author's own work.

Then, using GRETL software, the econometric equations for the analyzed cities were estimated in the form of an equation (4) for the adopted assumptions, in which the price of a dwelling and the price of 1 square meter of a dwelling in a given city were the response variables, while the explanatory variables included the period, location, construction material, standard, type of ownership, time of construction, floor space and the number of rooms. Table 2 presents the partial results of the housing price regression function in the cities under study. ${ }^{4}$

Table 2

Partial results of the housing price regression function in the analyzed cities in the years 2008-2012

\begin{tabular}{cccccc}
\hline \multicolumn{7}{c}{ Lodz } & Poznan & Warsaw & Wroclaw \\
\hline Const. & 11.5975 & 11.3375 & 11.6172 & 12.1185 & 11.8584 \\
\hline q_2 & -0.0201503 & -0.0334593 & -0.0157318 & -0.00659225 & -0.00276856 \\
\hline q_3 & -0.0434607 & -0.0416994 & -0.0475805 & -0.0253723 & -0.0186938 \\
\hline q_4 & -0.0542424 & -0.0439492 & -0.0691635 & -0.0341056 & -0.04335866 \\
\hline q_5 & -0.0976807 & -0.0829592 & -0.108193 & -0.0810475 & -0.0843437 \\
\hline q_6 & -0.0941837 & -0.0820447 & -0.115205 & -0.0764769 & -0.0765865 \\
\hline q_7 & -0.0862513 & -0.0917742 & -0.103602 & -0.0797938 & -0.0660188 \\
\hline q_8 & -0.0772255 & -0.0745589 & -0.0958677 & -0.0622852 & -0.055269 \\
\hline q_9 & -0.0580123 & -0.0610287 & -0.0775928 & -0.052608 & -0.0390844 \\
\hline q_10 & -0.0562033 & -0.054284 & -0.0905625 & -0.0501486 & -0.0646123 \\
\hline q_11 & -0.0438854 & -0.0601108 & -0.0760297 & -0.0553295 & -0.0540342 \\
\hline q_12 & -0.0485365 & -0.0630065 & -0.0738694 & -0.0651347 & -0.0430275 \\
\hline
\end{tabular}

4 The table does not contain the regression coefficients for localization variables. 
VERSITA

\begin{tabular}{cccccc}
\hline q_13 & -0.0365015 & -0.0373799 & -0.0987183 & -0.056297 & -0.0677261 \\
\hline q_14 & -0.052981 & -0.0681345 & -0.089521 & -0.0471016 & -0.0719836 \\
\hline q_15 & -0.075754 & -0.0815241 & -0.104424 & -0.0822994 & -0.0904496 \\
\hline q_16 & -0.104738 & -0.103022 & -0.114914 & -0.09465 & -0.110069 \\
\hline q_17 & -0.104379 & -0.109532 & -0.107893 & -0.102527 & -0.140717 \\
\hline q_18 & -0.114129 & -0.126352 & -0.130915 & -0.118341 & -0.144824 \\
\hline q_19 & -0.134864 & -0.145827 & -0.140562 & -0.136764 & -0.181578 \\
\hline q_20 & -0.142682 & -0.146103 & -0.127372 & -0.142317 & -0.186125 \\
\hline ob_1 & -0.00728325 & -0.317173 & -0.216281 & -0.0173109 & -0.126277 \\
\hline ob_2 & -0.047478 & -0.138974 & -0.148124 & -0.124657 & -0.060604 \\
\hline pow & 0.0156182 & 0.0182715 & 0.013838 & 0.01522 & 0.0141343 \\
\hline p & 0.0192897 & 0.0168683 & 0.0101271 & 0.0139623 & 0.00666853 \\
\hline m & 0.0452764 & & 0.0362408 & 0.0310298 & 0.0198048 \\
\hline s & 0.0308846 & 0.0527037 & 0.0517002 & 0.0307234 & 0.0431736 \\
\hline pw & 0.0252434 & & 0.05771 & 0.0390401 & 0.031007 \\
\hline
\end{tabular}

Table 2 continued

\begin{tabular}{|c|c|c|c|c|c|}
\hline & \multicolumn{5}{|c|}{ For the price of 1 square meter of a dwelling } \\
\hline & Cracow & Lodz & Poznan & Warsaw & Wroclaw \\
\hline const & 8.56653 & 8.32773 & 8.53953 & 9.04802 & 8.78916 \\
\hline q_2 & -0.02518 & -0.02389 & -0.01771 & -0.00649 & -0.00807 \\
\hline q_3 & -0.04142 & -0.03395 & -0.0423 & -0.02247 & -0.01542 \\
\hline q_4 & -0.05894 & -0.04513 & -0.06566 & -0.03473 & -0.03695 \\
\hline q_5 & -0.09751 & -0.07528 & -0.10684 & -0.07855 & -0.076 \\
\hline q_6 & -0.10025 & -0.08272 & -0.11263 & -0.077 & -0.0777 \\
\hline q_7 & -0.09131 & -0.08874 & -0.09976 & -0.07762 & -0.06407 \\
\hline q_8 & -0.08325 & -0.07717 & -0.09615 & -0.06238 & -0.05424 \\
\hline q_9 & -0.06736 & -0.0611 & -0.07296 & -0.05596 & -0.04015 \\
\hline q_10 & -0.0622 & -0.05516 & -0.08748 & -0.05784 & -0.06322 \\
\hline q_11 & -0.04962 & -0.0636 & -0.06915 & -0.05914 & -0.05042 \\
\hline q_12 & -0.06223 & -0.0677 & -0.07671 & -0.06979 & -0.0371 \\
\hline q_13 & -0.04072 & -0.04713 & -0.09816 & -0.05936 & -0.06206 \\
\hline q_14 & -0.05765 & -0.07734 & -0.08885 & -0.04879 & -0.06449 \\
\hline q_15 & -0.08622 & -0.089 & -0.10072 & -0.08411 & -0.08674 \\
\hline q_16 & -0.1121 & -0.11271 & -0.10812 & -0.09782 & -0.10701 \\
\hline q_17 & -0.11665 & -0.10862 & -0.09855 & -0.10555 & -0.13316 \\
\hline q_18 & -0.11786 & -0.13386 & -0.12829 & -0.12019 & -0.14362 \\
\hline q_19 & -0.1422 & -0.15214 & -0.13734 & -0.13665 & -0.18246 \\
\hline q_20 & -0.1501 & -0.15378 & -0.12199 & -0.1444 & -0.18717 \\
\hline ob_1 & 0.023703 & -0.26258 & -0.17724 & -0.01328 & -0.09702 \\
\hline ob_2 & -0.03468 & -0.14985 & -0.14357 & -0.10826 & -0.03867 \\
\hline pow & -0.00156 & 0.000885 & -0.00248 & -0.00065 & -0.00264 \\
\hline $\mathrm{p}$ & 0.018194 & 0.016506 & 0.011543 & 0.012031 & 0.00623 \\
\hline $\mathrm{m}$ & 0.058899 & & 0.048473 & 0.037121 & 0.027183 \\
\hline $\mathrm{s}$ & 0.031675 & 0.051562 & 0.049416 & 0.032058 & 0.045036 \\
\hline pw & 0.025842 & & 0.060465 & 0.043076 & 0.031639 \\
\hline
\end{tabular}

Source: author's own work.

From the obtained results, it is possible to conclude that the explanatory variables used in the equations explain - in $85 \%$ (for full prices) and in $45 \%$ (for prices of $1 \mathrm{~m}^{2}$ ) - the variability of prices in the cities under study during the years 2008-2012. Moreover, the majority of variables applied in the models turned out to be statistically relevant.

Next, the hedonic housing price and hedonic price of 1 square metre in 2008-2012 were established 
for the particular cities (states of features as the averages from the period under study were adopted). Figures 2 and 3 present the hedonic housing prices in Cracow, Lodz, Poznan, Warsaw and Wroclaw in the analyzed time period.
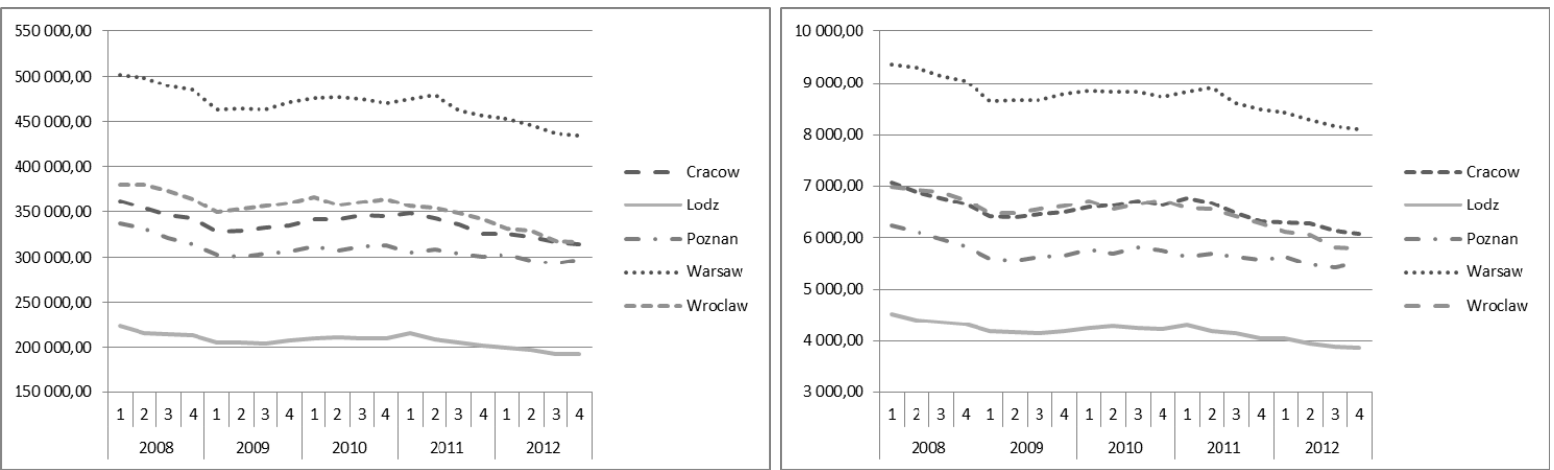

Fig. 2 and 3. Hedonic price and hedonic price of 1 square meter of dwellings in Cracow, Lodz, Poznan, Warsaw and Wroclaw in 2008-2012. Source: author's own work.

Another source of information used in the study were the transaction prices of apartments with limited rights of ownership in Poznan in the period of 1996-2010. Data on over 18,800 transactions were collected. Next, the average prices and prices of $1 \mathrm{~m}^{2}$ of apartments were established for the period of 1996-2010 (states of features as the averages from the period under study were adopted). Figures 4 and 5 present the average prices and prices of $1 \mathrm{~m}^{2}$ of apartments with limited rights of ownership in Poznan in the years 1996-2010.
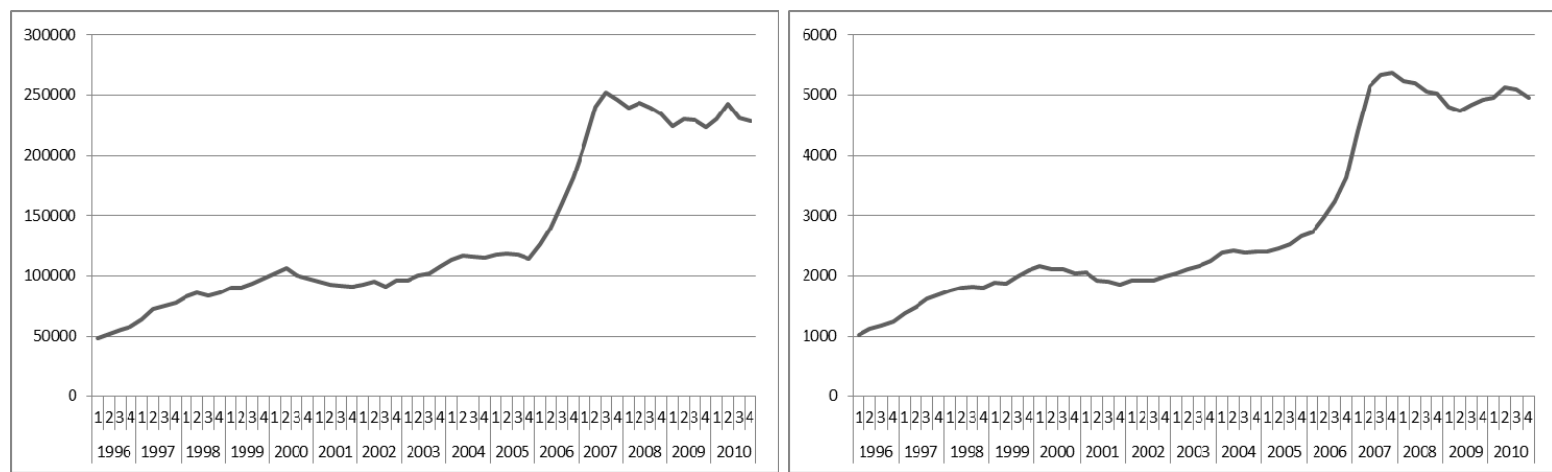

Fig. 4 and 5. The average prices and prices of $1 \mathrm{~m}^{2}$ of apartments with limited rights of ownership in Poznan in the period of 1996-2010. Source: author's own work.

\section{An identification of the seasonality of prices in the housing market}

The most popular and most frequently used methods of distinguishing seasonal fluctuations from time series include the X-12 ARIMA model ${ }^{5}$ and the TRAMO-SEATS procedure. The first method was developed by the U.S. Bureau of the Census, while the second - by V. Gómez and A. Maravall. ${ }^{6}$ Both tools combine the classic decomposition of a time series into components connected to a trend, seasonality and an irregular factor, with modeling time series using ARIMA models. By applying these methods for smoothing time series, it was possible to remove seasonal fluctuations and random components from the series.

In order to distinguish seasonal fluctuations in the time series of apartment prices in the analyzed cities in 1996-2012 and 2008-2012, the X-12 ARIMA procedure was used. The most frequently used tests for identifying seasonality in a given time series include:

\footnotetext{
5 The method was described in detail in: D.F. Findley, B.C. Monsell, W.R. Bell, M.C. Otto i B. Chen, New Capabilities and Methods of the X-12 ARIMA Seasonal Adjustment Program, Journal of Business and Economic Statistics 1998, vol. 16, ss. 127-152.

6V. Gomez, A. Marvall, Programs TRAMO (Time series Regression with Arima noise, Missing observations, and Outliers) and SEATS (Signal Extraction in Arima Time Series). Instructions for the User, Banco de Espana, Working Paper 1996, no. 9628.
} 
- the parametric F-test,

- the Kruskal-Wallis test.

The results of the X-12 ARIMA procedure include, among other things, information about both of these tests. In the case of the analyzed time series, both the short-term (2008-2012) as well as the longterm (1996-2012) ones, the tests showed no seasonality. Real values were estimated as well, but the above mentioned tests once again indicated the non-occurrence of seasonality. Only for the time series of the average prices of apartments in Poznan with limited rights of ownership in the period of 19962010 did the parametric F-test and the Kruskal-Wallis test confirm the occurrence of seasonal fluctuations (the results were negative for the average prices of $1 \mathrm{~m}^{2}$ ). Figure 6 shows the seasonal component in the time series of the average prices of apartments with limited rights of ownership in Poznan in the period of 1996-2010.

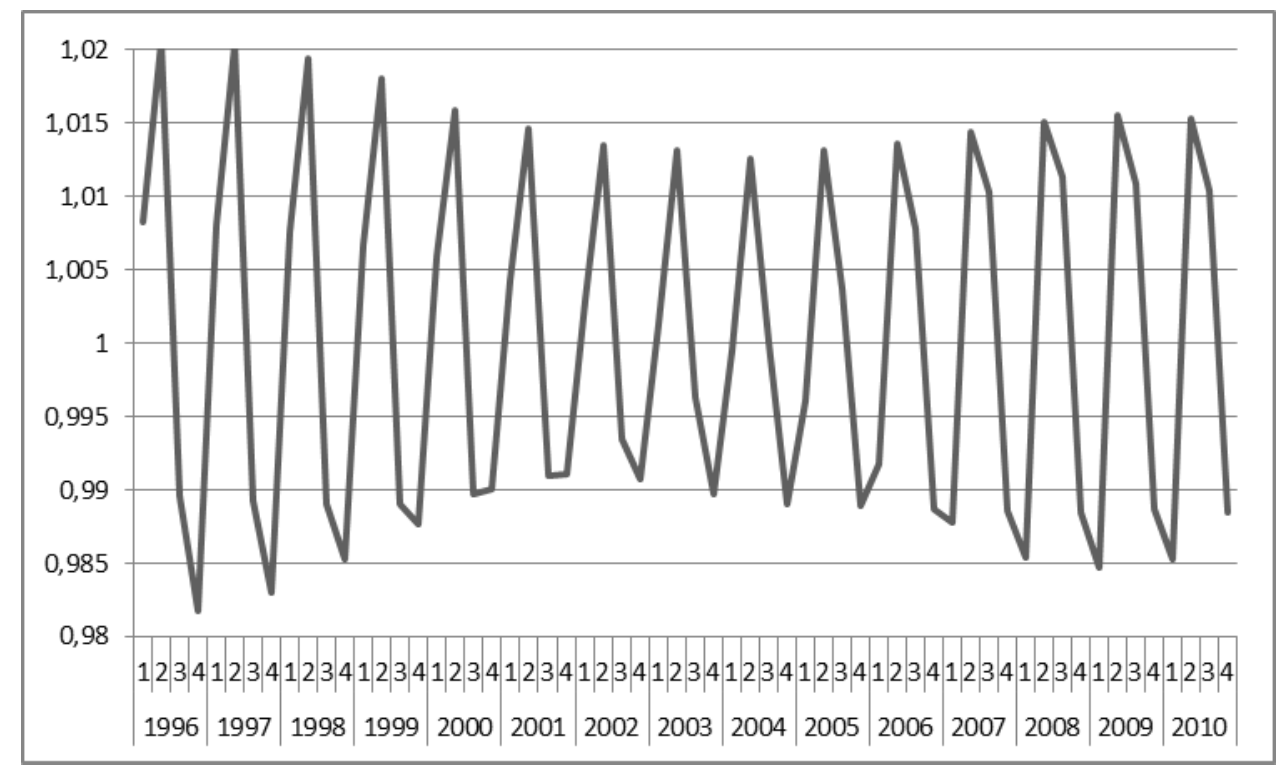

Fig. 6. The seasonal component in the time series of the average prices of apartments with limited rights of ownership in Poznan in the period of 1996-2010. Source: author's own work.

The identified seasonal fluctuations for the transaction prices of apartments in Poznan with limited rights of ownership in the period of 1996-2010 indicate that prices of apartments in the $2^{\text {nd }}$ and $3^{\text {rd }}$ quarter are higher than the average prices for a given year, and lower in the $1^{\text {st }}$ and $4^{\text {th }}$ one.

\section{Conclusion}

In this paper, an attempt was made to identify the seasonal component in time series of apartment prices in selected cities of Poland. The study was conducted for time series established on the basis of simple and complex methods. The results of the tests for the occurrence of seasonality in time series indicate that the seasonal component does not occur in the case of the analyzed series. The obtained results may be biased because asking prices were used (the supply side), as well as a method of designing the housing price index that does not allow a "pure price change" to be identified in the case of the time series from 1996-2012. Seasonality in a number of transactions and prices in the UK and the USA is mainly attributed to two assumptions (KAJUTH , SCHMIDT 2011):

- married couples with children prefer to move to a new place in the summer (in the vacation period), because it would be more expensive to move during the school year,

- moreover, married couples prefer owning a house or an apartment rather than renting, and most people get married in the spring or summer.

Given the above, as well as the fact that most people in Poland get married in the $2^{\text {nd }}$ and $3^{\text {rd }}$ quarters, it is difficult to discover seasonality in asking prices, which constitute the supply side of the housing market.

The seasonal component was found in the case of transaction prices of apartments in Poznan in 1996-2010. The results confirmed that prices of apartments were higher in the $2^{\text {nd }}$ and $3^{\text {th }}$ quarters and lower in the $1^{\text {st }}$ and $4^{\text {th }}$ quarters than the average prices for a given year. It should be pointed out that no seasonal component was identified in the time series of the price of $1 \mathrm{~m}^{2}$ of apartments. The reason 
for this may be the fact that most apartments in Poznan (in 2010-2011) were bought by married couples, and most transactions were entered into in the $2^{\text {nd }}$ and $3^{\text {rd }}$ quarters. Moreover, married couples bought, on average, the largest apartments, which meant that they were also the most expensive ones.

\section{References}

GAWRON H., 2006, Opłacalność inwestowania na rynku nieruchomości, Wyd. AE w Poznaniu, Poznań.

Goodman JoHn L., JR., 1993, A Housing Market Matching Model of the Seasonality in Geographic Mobility, Journal of Real Estate Research.

HANDBOOK ON RPPI VERSION 3.0 JANUARY 2011.

KAJUTH F., SCHMIDT T., 2011, Seasonality in house prices, Series 1: Economic Studies, Deutsche Bundesbank, Discussion Paper.

KAPLANSKI G., LeVY H., 2012, Real Estate Prices: An International Study of Seasonality's Sentiment Effect, Journal of Empirical Finance, Vol. 19, Issue 1.

KONIUNKTURA GOSPODARCZA POLSKI, ANALIZA GRUP PRODUKTOWYCH., 1997, RED. M. REKOWSKI, WYD. AE W POZNANIU, POZNAŃ.

KONIUNKTURA GOSPODARCZA, 1982, Red. Z. Kowalczyk, PWE, Warszawa.

KONIUNKTURA NA RYNKU BANKOWYM I UBEZPIECZENIOWYM W POLSCE, 2001, Red. J. Garczarczyk, Akademia Ekonomiczna w Poznaniu - Katedra Badań Marketingowych, Poznań.

KuO CHIONG-LONG, 1996, Serial Correlation and Seasonality in the Real Estate Market, Journal of Real Estate Finance and Economics.

KRUSZKA M., 2003, Synchronizacja wahań koniunkturalnych w gospodarce krajów rozwiniętych, Wiadomości Statystyczne, 6 .

LUBIŃSKI M., 2002, Analiza koniunktury i badania rynków, Dom Wydawniczy Elipsa, Warszawa.

Miller, N., SAH V., Sklarz M., PAMPulov S., 2011, Seasonality in Home Prices: Evidence from the CBSAs, Working Paper, Collateral Analytics and University of San Diego.

TrojaneK R., 2008, Wahania cen na rynku mieszkaniowym, Wyd. AE w Poznaniu, Poznań. 


\section{REAL ESTATE MANAGEMENT AND VALUATION (REMV)}

Previously

„STUDIA I MATERIAŁY TOWARZYSTWA NAUKOWEGO NIERUCHOMOŚCI” "Journal of the Polish Real Estate Scientific Society"

\section{DECLARATION ON THE ORIGINAL VERSION}

Editors Board reports that the journal is MAIN VERSION edition of "ELECTRONIC (on-line)"

Status on 02 January 2013.

REMV Editorial Board 


\title{
REAL ESTATE MANAGEMENT AND VALUATION (REMV)
}

\author{
Previously \\ „STUDIA I MATERIAŁY TOWARZYSTWA NAUKOWEGO NIERUCHOMOŚCI” \\ "Journal of the Polish Real Estate Scientific Society"
}

\section{RADA NAUKOWA SCIENTIFIC COUNCIL}

prof. dr hab. Ewa KUCHARSKA-STASIAK

(Uniwersytet Łódzki, University of Lodz, Poland)

(przewodnicząca, chairman)

\begin{abstract}
dr hab. Radosław WiśNIEWSKI, prof. UWM
(wiceprzewodniczący, vice-chairman)

prof. Rachelle ALTERMAN

(Technion - Israel Institute of Technology, IsraeI)

Aurílio Sérgio C. CAIADO

(University de Sorocaba, Brazil)

prof. dr hab. inż. Andrzej HOPFER
\end{abstract}

(Uniwersytet Warmińsko-Mazurski w Olsztynie, University of Warmia and Mazury in Olsztyn, Poland)

(Wyższa Szkoła Gospodarowania Nieruchomościami, School of Real Estate Management, Poland) prof. Davorin Kereković

(University of Zagreb, Croatia)

prof. George MATYSIAK

(University of Reading, United Kingdom)

prof. dr hab. inż. Bogdan Ney

(Instytut Geodezji i Kartografii w Warszawie, Institut of Geodesy and Cartography in Warsaw, Poland)

prof. K.N. Oleksiy TERESCHUK

(Chernihiv State Institute of Economic and Management, Ukraine)

prof. Kauko Jussi VIITANEN

(Helsinki University of Technology, Finland)

prof. Ian WILLIAMSON

(University of Melbourne, Australia)

(członkowie, members)

dr inż. Mirosław Bełej

(Uniwersytet Warmińsko-Mazurski w Olsztynie, University of Warmia and Mazury in Olsztyn, Poland) (sekretarz secretary)

\section{REDAKTOR NACZELNY EDITOR-IN-CHIEF}

prof. dr hab. inż. Sabina ŹRÓBEK

(Uniwersytet Warmińsko-Mazurski w Olsztynie, University of Warmia and Mazury in Olsztyn, Poland) 


\section{REDAKTORZY JEZZYKOWI}

LANGUAGE EDITORS

mgr Aleksandra RÓŻAŃSKA

(Towarzystwo Naukowe Nieruchomości. Polish Real Estate Scientific Society, Poland)

Język polski / Polish

prof. Richard GROVER

(Oxford Brookes University, United Kingdom)

Język angielski / English

\section{REDAKTOR STATYSTYCZNY}

STATISTICAL EDITOR

prof. zw. dr hab. Józef HOZER

(Uniwersytet Szczeciński, University of Szczecin, Poland)

\section{REDAKTORZY TEMATYCZNI}

\section{THEMATIC EDITORS}

prof. dr hab. inż. Ryszard ŹRÓBEK

(Uniwersytet Warmińsko-Mazurski w Olsztynie, University of Warmia and Mazury in Olsztyn, Poland)

dr hab. Antoni SOBCZAK, prof. WSL

(Wyższa Szkoła Logistyki, Poznan School of Logistics, Poland)

dr hab. Radosław WIŚNIEWSKI, prof. UWM

(Uniwersytet Warmińsko-Mazurski w Olsztynie, University of Warmia and Mazury in Olsztyn, Poland)

Stan 02 stycznia 2013 roku.

Status on 02 January 2013.

Redakcja REMV

REMV Editorial Board 


\section{REAL ESTATE MANAGEMENT AND VALUATION (REMV) \\ Previously „STUDIA I MATERIAŁY TOWARZYSTWA NAUKOWEGO NIERUCHOMOŚCI” "Journal of the Polish Real Estate Scientific Society"}

\section{RECENZENCI (REVIEWERS)}

prof. dr hab. inż. Zdzisław ADAMCZEWSKI

(Politechnika Warszawska, Warsaw University of Technology, Poland) prof. dr hab. inż. Józef CZAJA

(Akademia Górniczo-Hutniczo w Krakowie, AGH University of Science and Technology, Poland) prof. Maurizio D'AMATO

(Technical University Politecnico di Bari, Italy) prof. Peter DENT

(Oxford Brookes University, United Kingdom) dr hab. Iwona Foryś

(Uniwersytet Szczeciński, University of Szczecin, Poland) assoc. prof. Tom KAUKO

(Norwegian University of Science and Technology, Norway)

assoc. prof. dr. Esra Dardagan KIBAR

(University of Ankara, Turkey) $\mathrm{dr}$ hab. Sebastian KоКОT

(Uniwersytet Szczeciński, University of Szczecin, Poland)

prof. dr hab. Adam NALEPKA

(Uniwersytet Ekonomiczny w Krakowie, Cracow University of Economics, Poland)

prof. dr. Sebnem Akipek OCAL

(University of Ankara, Turkey)

dr Sally SIMS

(Oxford Brookes University, United Kingdom)

prof. Nikolaj Siniak

(Belarusian State Technological University, Belarus)

prof. Håvard STEINSHOLT

(Norwegian University of Life Science, Norway)

prof. dr. Maruška ŠUBIC-KovAČ

(University of Ljubljana, Slovenia)

dr hab. inż. Piotr PARZYCH, prof. AGH

(Akademia Hutniczo-Techniczna w Krakowie, AGH University of Science and Technology, Poland) dr hab. Ewa SIEMIŃSKA, prof. UMK

(Uniwersytet Mikołaja Kopernika, Nicolaus Copernicus University, Poland)

prof. Charles SZYPSZAK

(School of Government, USA)

prof. Nguyen Khac THOI

(University of Hanoi, Vietnam) 
dr hab. Maria TROJANEK, prof. UEP

(Uniwersytet Ekonomiczny w Poznaniu, Poznań University of Economics, Poland)

prof. dr hab. inż. Zofia WIĘCKOWICZ

(Uniwersytet Przyrodniczy we Wrocławiu, WROCŁAW UNIVERSITY OF ENVIRONMENTAL AND LIFE SCIENCES, Poland)

prof. dr hab. inż. Wojciech WILKOWSKI

(Politechnika Warszawska, Warsaw University of Technology, Poland)

prof. dr.-ing Winirch Voß

(Leibniz Universität Hannover, Germany)

dr hab. Magdalena Załęczna

(Uniwersytet Łódzki, University of Lodz, Poland)

Stan 27 grudnia 2013 roku.

Status on 27 December 2013.

Redakcja REMV

REMV Editorial Board 